\title{
Analysis of lysine-dependent yeast sporulation: a decrease in cyclic AMP is not required for initiation of meiosis and sporulation in Saccharomyces cerevisiae
}

\author{
Tetsuyoshi Suizu, ${ }^{1}$ Hiroko Tsutsumi, ${ }^{1}$ Akitsugu Kawado, ${ }^{1}$ Tomoko Inose, ${ }^{2}$ \\ Koji Suginami ${ }^{1}$ and Kousaku Murata ${ }^{2}$
}

Author for correspondence: Kousaku Murata. Tel: +8177433 6902. Fax: +81774 333004.

\footnotetext{
1 Research Institute, Gekkeikan Sake, Co., Ltd, Kyoto, Kyoto 612, Japan

2 Research Institute for Food Science, Kyoto University, Uji, Kyoto 611, Japan
}

\begin{abstract}
Cells of the yeast Saccharomyces cerevisiae sporulated in nutrient-rich medium containing L-lysine. Sporulation was specific to the presence of L-lysine and was initiated when the cellular content of this basic amino acid reached approximately $0.2-0.5 \mathrm{mmol}$ (g cells) ${ }^{-1}$, at early stationary phase. The formation of asci was most efficient at pH 7.0 and 50-100 mM L-lysine; in these optimum conditions, the sporulation frequency reached about $60 \%$ after $5 \mathrm{~d}$ incubation. The L-lysine-dependent sporulation system in nutrient-rich conditions was distinct from the currently used potassium-acetate-dependent system in nutrient-deficient conditions. Analysis of the L-lysine-dependent system indicated that, prior to entrance into meiosis and/or sporulation processes, the yeast cells change in shape, their pool sizes for L-cysteine and glutathione alter, and they synthesize a protein with a molecular mass of $15 \mathrm{kDa}$. A low level of CAMP was not required for the entrance into meiosis and/or sporulation.
\end{abstract}

Keywords: Saccharomyces cerevisiae, meiosis, sporulation, L-lysine, cyclic AMP

\section{INTRODUCTION}

When vegetative cells are transferred to nutrient-deprived medium containing potassium acetate, $a / \alpha$ diploid cells of the yeast Saccharomyces cerevisiae can enter into meiosis and subsequent sporulation processes. Nutrient-deprived medium containing potassium acetate has frequently been utilized for the analysis of meiosis and/or sporulation processes of yeast cells. However, $\mathbf{a} / \alpha$ diploid yeast cells have been known to be able to sporulate even in medium with sufficient nutrients; nutritional conditions for sporulation have been extensively studied by Freese $e t$ al. (1982, 1984) and Olempska-Beer \& Freese (1987). Our preliminary study (Kawado et al., 1993) also indicated that a/ $\alpha$ diploid yeast cells can enter into meiosis and sporulation processes on a nutrient-rich agar medium containing $\mathrm{L}$ - or D-lysine.

In the present study, we characterized a novel lysinedependent sporulation system for $S$. cerevisiae in nutrientrich conditions, and used the system to examine the hypothesis of Matsumoto et al. $(1983,1985)$ that initiation of meiosis requires a low level of cAMP.

\section{METHODS}

Yeast strains. The wild-type a/ $\alpha$ diploid strains of Saccharomyces cerevisiae AKU 4011 (Kawado et al., 1993), 2HY-1 and IFO 2034 were used. Strain AKU 4011 was obtained from the Laboratory of Industrial Microbiology, Department of Food Science and Technology, Kyoto University, Kyoto, Japan, and was used throughout the study. Strains 2HY-1 and IFO 2034 were from Gekkeikan Sake Co., Kyoto, Japan, and were used as controls.

Sporulation conditions. Cells of all three strains were pregrown at $30{ }^{\circ} \mathrm{C}$ overnight in YPD nutrient medium $[2.0 \%$ $(\mathrm{w} / \mathrm{v})$ glucose, $1.0 \%(\mathrm{w} / \mathrm{v}$ ) Bactopeptone (Difco), $0.5 \%$ (w/v) yeast extract (Difco)]. The $\mathrm{pH}$ of the medium was adjusted to $5 \cdot 0$ with $0 \cdot 1 \mathrm{M} \mathrm{HCl}$. The cells were collected by centrifugation, washed twice in chilled water, and $0.1 \mathrm{ml}$ of the cell suspension (approximately $10^{5}$ cells) was transferred to $20 \mathrm{ml}$ nutrient-rich sporulation medium (NR medium) in a $50 \mathrm{ml}$ Erlenmeyer flask. NR medium ( $\mathrm{pH} 7 \cdot 0$ ) consisted of $1.0 \%(\mathrm{w} / \mathrm{v})$ glucose, $0.3 \%$ (w/v) Yeast Nitrogen Base w/o amino acids (Difco), $0.01 \%$ $(\mathrm{w} / \mathrm{v}$ ) yeast extract and $100 \mathrm{mM}$ PIPES. To induce sporulation in yeast cells, L-lysine was separately sterilized and added at $0.1 \mathrm{M}$ to $\mathrm{NR}$ medium. The medium was shaken at $30^{\circ} \mathrm{C}(3 \mathrm{~cm}$ stroke, 120 r.p.m.) for several days. Growth was determined by measuring $\mathrm{OD}_{610}$ after dilution of cultures. The turbidity $\left(\mathrm{OD}_{610}\right)$ can be converted to cell number $\left(N, \mathrm{ml}^{-1}\right)$ using the 
equation $N=\mathrm{OD}_{610} \times 4 \times 10^{6}$. Formation of asci was microscopically confirmed and the sporulation frequency was determined by scoring the number of asci in a total cell population of at least 300. Washed YPD pre-grown cells were also transferred to $20 \mathrm{ml}$ nutrient-deprived sporulation medium (ND medium) in a $50 \mathrm{ml}$ Erlenmeyer flask. ND medium consisted of $1.5 \%(\mathrm{w} / \mathrm{v})$ potassium acetate $(\mathrm{pH} 7 \cdot 0)$ and initial cell concentration was adjusted to approximately $10^{7} \mathrm{ml}^{-1}$. Incubations in ND medium were carried out as above.

Amino acid and glutathione assays. Cells of strain 4011 were washed twice in chilled water, resuspended in chilled water to give a cell concentration of $30 \mathrm{mg}$ (wet wt) $\mathrm{ml}^{-1}$, and $0.1 \mathrm{ml}$ of the suspension was treated at $100^{\circ} \mathrm{C}$ for $5 \mathrm{~min}$. The cells were removed by centrifugation and the resulting supernatant was used for amino acid and glutathione assays. Amino acid composition was determined by an amino acid analyser (Hitachi L8500). Total glutathione (reduced and oxidized forms) was determined enzymically by the method of Tietze (1969).

Measurement of CAMP. The cAMP content of cells of strain 4011 was determined as described previously (Kano et al., 1983). Briefly, the cells $(0 \cdot 1 \mathrm{~g}$ wet $\mathrm{wt})$ grown in NR medium in the presence or absence of $\mathrm{L}$-lysine were extracted for CAMP with $20 \mathrm{ml} 6.0 \%(\mathrm{w} / \mathrm{v})$ perchloric acid for $20 \mathrm{~min}$ at $4{ }^{\circ} \mathrm{C}$. After neutralization with $1.5 \mathrm{M} \mathrm{KOH}$, the mixture was made up to $5.0 \mathrm{ml}$, centrifuged at 3000 r.p.m. for $10 \mathrm{~min}$, and the resulting clear solution was used for the radioimmunoassay of cAMP by using a cAMP assay kit (Yamasa Shoyu Co.). No appreciable loss or degradation of cAMP was observed during the assay period and duplicate determinations were made for each sample.

Protein analysis. After washing once in chilled water, cells of strain 4011 were suspended in $5.0 \mathrm{mM}$ potassium phosphate buffer $(\mathrm{pH} 7.5)$ and disrupted at $5{ }^{\circ} \mathrm{C}$ for $4 \mathrm{~min}$ by a Braun homogenizer. The homogenate was centrifuged at $25000 \mathrm{~g}$, $4{ }^{\circ} \mathrm{C}$, for $30 \mathrm{~min}$ and proteins in the supernatant were analysed by SDS-PAGE (Laemmli, 1970).

\section{RESULTS}

\section{Properties of the L-lysine-dependent sporulation system}

The properties of L-lysine-dependent sporulation system were determined by using strain 4011 .

Effect of $\mathrm{pH}$. The effect of $\mathrm{pH}$ on sporulation was determined by varying the $\mathrm{pH}$ of $\mathrm{NR}$ medium with $\mathrm{L}-$ lysine at $0.1 \mathrm{M}$ (Fig. 1). Growth was maximal at $\mathrm{pH} 6.0$, and was completely arrested at $\mathrm{pH} 8 \cdot 0$. Formation of asci was greatest at $\mathrm{pH} 7 \cdot 0$, and decreased with the decrease in initial $\mathrm{pH}$ of NR medium.

Effect of L-lysine concentration. The concentration of $\mathrm{L}$ lysine in NR medium ( $\mathrm{pH} 7 \cdot 0$ ) was varied from 0 to $300 \mathrm{mM}$ without significant growth inhibition (Fig. 2). The maximum formation of asci was attained at $100 \mathrm{mM}$ L-lysine. The intracellular L-lysine content increased with extracellular L-lysine concentration and reached a plateau [1.3-1.4 mmol $\left.(\mathrm{g} \text { cells })^{-1}\right]$ when L-lysine was present at more than $100 \mathrm{mM}$.

Effect of carbon source. Sucrose $(1.0 \%, \mathrm{w} / \mathrm{v})$ was used as a replacement for glucose as carbon source, without any appreciable decrease in sporulation frequency or growth

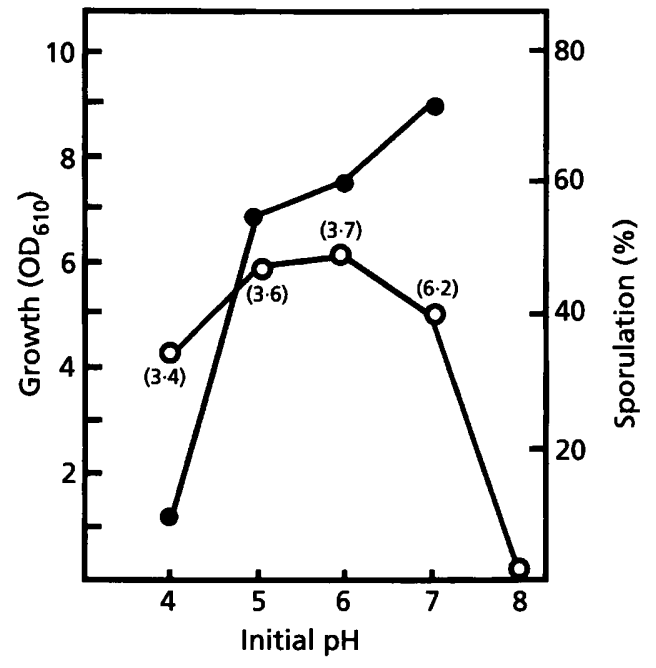

Fig. 1. Effect of pH on sporulation. Cells were incubated in NR medium containing $0.1 \mathrm{M}$ L-lysine, adjusted to $\mathrm{pH} 4.0,5.0,6.0$, 7.0 and 8.0 . The final pH of the medium after $5 \mathrm{~d}$ incubation is indicated in parentheses in the figure. Growth $\left(O D_{610}\right)(O)$ and sporulation (O) were determined after $5 \mathrm{~d}$ incubation.

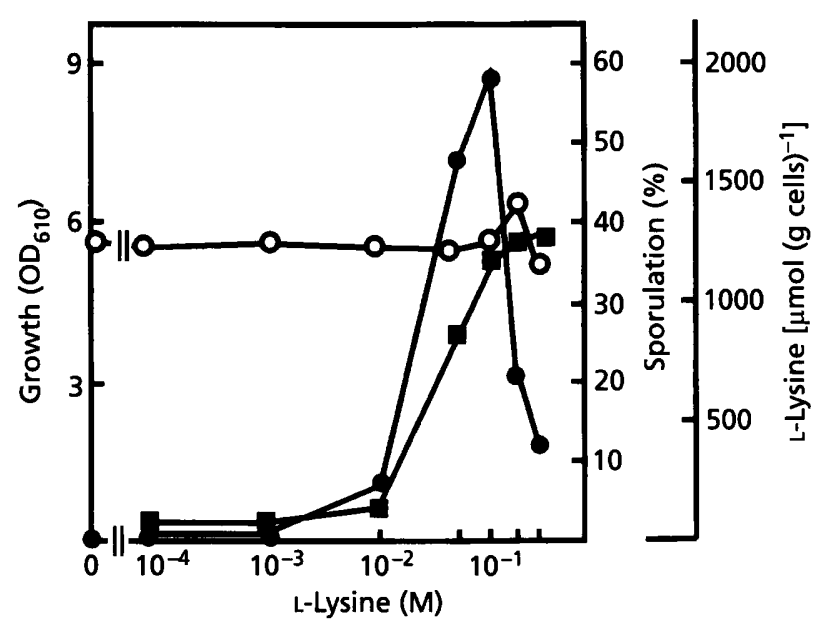

Fig. 2. Effect of L-lysine on sporulation. Cells were incubated in NR medium (pH 7.0) containing L-lysine at various concentrations. Growth $\left(O_{610}\right)(O)$, sporulation (O) and intracellular L-lysine level $(G)$ were determined after $5 \mathrm{~d}$ incubation.

(data not shown). Fructose, maltose, mannose and galactose were also effective, although both growth and sporulation frequency were considerably lowered when these sugars were used at $1.0 \%(\mathrm{w} / \mathrm{v})$ (data not shown). LLysine failed to induce sporulation in ND medium, when added in place of potassium acetate (Table 1). The use of L-lysine together with potassium acetate in ND medium resulted in a marked decrease in sporulation frequency.

Time course of ascus formation. Cells were grown in NR medium (initial $\mathrm{pH} 7 \cdot 0$ ) containing L-lysine at various 
Table 1. Effect of potassium acetate and L-lysine on induction of sporulation

Cells were incubated at $30^{\circ} \mathrm{C}$ for $5 \mathrm{~d}$ in nutrient-deprived ND medium ( $\mathrm{pH} 7 \cdot 0$ ) supplemented with potassium acetate (AcK, $1.5 \%$, and/or L-lysine $(0 \cdot 1 \mathrm{M})$. The initial cell concentration was adjusted to approximately $10^{7} \mathrm{ml}^{-1}$. Final $\mathrm{pH}$, sporulation and types of ascus were determined.

\begin{tabular}{|c|c|c|c|c|c|c|}
\hline \multirow{2}{*}{$\begin{array}{l}\text { Addition to } \\
\text { ND medium }\end{array}$} & \multirow{2}{*}{$\begin{array}{c}\text { Final } \\
\mathrm{pH}\end{array}$} & \multirow{2}{*}{$\begin{array}{c}\text { Sporulation } \\
(\%)\end{array}$} & \multicolumn{4}{|c|}{ Types of ascus (\%) } \\
\hline & & & $\begin{array}{c}1- \\
\text { spored }\end{array}$ & $\begin{array}{c}2- \\
\text { spored }\end{array}$ & $\begin{array}{c}3- \\
\text { spored }\end{array}$ & $\begin{array}{c}\text { 4- } \\
\text { spored }\end{array}$ \\
\hline None & 6.55 & 0 & - & - & - & - \\
\hline AcK & $9 \cdot 14$ & $82 \cdot 6$ & 0 & 0 & $5 \cdot 4$ & $94 \cdot 5$ \\
\hline L-Lysine & $7 \cdot 27$ & 0 & - & - & - & - \\
\hline AcK + L-Lysine & $8 \cdot 01$ & $18 \cdot 6$ & 0 & 0 & $10 \cdot 4$ & $89 \cdot 6$ \\
\hline
\end{tabular}

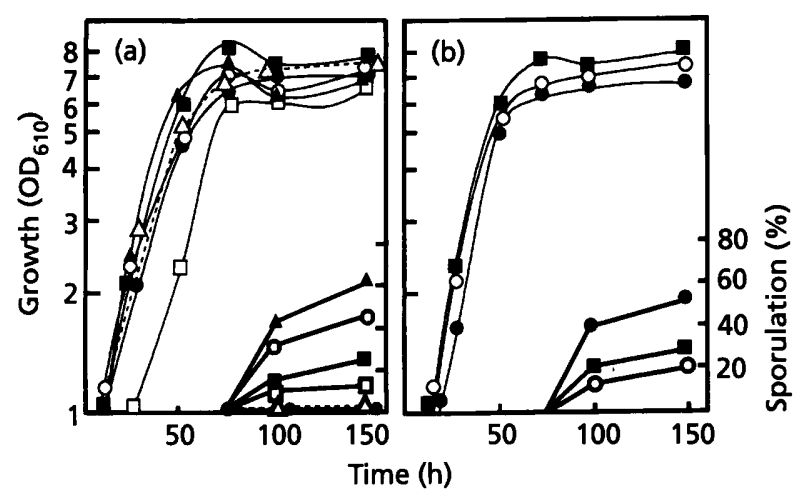

Fig. 3. Time course of ascus formation. (a) Cells of strain 4011 were incubated in NR medium ( $\mathrm{pH} 7.0)$ containing L-lysine [solid lines: $0(0), 50(0), 100(\Delta), 200(\square)$ and $300(\square) \mathrm{mM}]$ or potassium acetate [dashed line: $1.5 \%(w / v)(\triangle)$ ]. (b) Cells of other strains [strains $4011(O), 2 \mathrm{HY}-1(O)$ and $2034(\square)$ ] were also incubated in NR medium containing $0.1 \mathrm{M}$ L-lysine. Growth $\left(O D_{610}\right)$ (solid and dashed thin lines) and sporulation (solid and dashed thick lines) were determined.

concentrations from 0 to $300 \mathrm{mM}$ (Fig. 3a). Irrespective of the L-lysine concentration, glucose in the medium was lost after $2 \mathrm{~d}$ incubation and the $\mathrm{pH}$ of the medium remained above 6.2 throughout the incubation period (data not shown). Turbidity of cultures in the medium with L-lysine initially increased, reached a maximum at early stationary phase, slightly declined just before the appearance of asci, and then increased at the final stage of growth. No asci were formed in the medium containing no added L-lysine, or when potassium acetate was used in NR medium in place of L-lysine. In the presence of $0.1 \mathrm{M}$ L-lysine, sporulation reached about $60 \%$ after $6 \mathrm{~d}$ incubation. As well as strain 4011, a/ $\alpha$ diploid strains of $S$. cerevisiae $2 \mathrm{HY}-1$ and 2034 were also found to sporulate in NR medium containing $0 \cdot 1 \mathrm{M}_{\mathrm{L}}$-lysine (Fig. $3 \mathrm{~b}$ ). The time courses of sporulation of these strains were very similar to that of strain 4011.

\section{Relations between sporulation and cellular components}

A typical sporulation experiment for $S$. cerevisiae 4011 was conducted in NR medium (initial $\mathrm{pH} 7 \cdot 0$ ) with $0 \cdot 1 \mathrm{M} \mathrm{L}$ lysine, and the changes in cell shapes and cellular components were compared with those of cells similarly grown in NR medium in the absence of added L-lysine (Fig. 4). Irrespective of the presence or absence of $\mathrm{L}$ lysine, glucose in the medium was lost after $2 \mathrm{~d}$ incubation, and the $\mathrm{pH}$ of the medium remained above 6.2 throughout the incubation period.

Sporulation and cell size. The cells in early stationary phase (incubation time $75 \mathrm{~h}$ in Fig. 4b) in L-lysine medium were round and larger in diameter than cells in the same growth phase (incubation time $75 \mathrm{~h}$ in Fig. 4a) in control medium without L-lysine (Fig. 5, top). The yeast cells sporulated only in the presence of L-lysine and asci, produced after about $6 \mathrm{~d}$ incubation (Fig. 4b), contained four spores (Fig. 5 , bottom).

Amino acids. Amino acid concentration in cells before the entrance into sporulation in ND medium with L-lysine (culture time 50 and $75 \mathrm{~h}$ in Fig. 4b) was determined and compared with that in cells grown for $50 \mathrm{~h}$ (Fig. 4a) in the absence of L-lysine (Table 2). In the presence of L-lysine, cellular levels of L-serine, L-cysteine (or L-cystine) and L-lysine significantly increased, whereas those of Lthreonine, L-glutamic acid, L-alanine and L-arginine decreased. The formation of asci began at the time when the intracellular L-lysine level reached about $0.5 \mathrm{mmol}$ (g cells) ${ }^{-1}$ (Fig. $4 \mathrm{~b}$ ), and continued during the period tested.

Total glutathione. A preliminary study indicated that glutathione was a prerequisite for sporulation in nutritiondeprived ND medium containing potassium acetate (Suizu et al., 1994a). In the L-lysine-dependent sporulation system, the tripeptide rapidly disappeared just before the entrance into sporulation, and was almost completely absent during sporulation (Fig. 4b). In control medium 


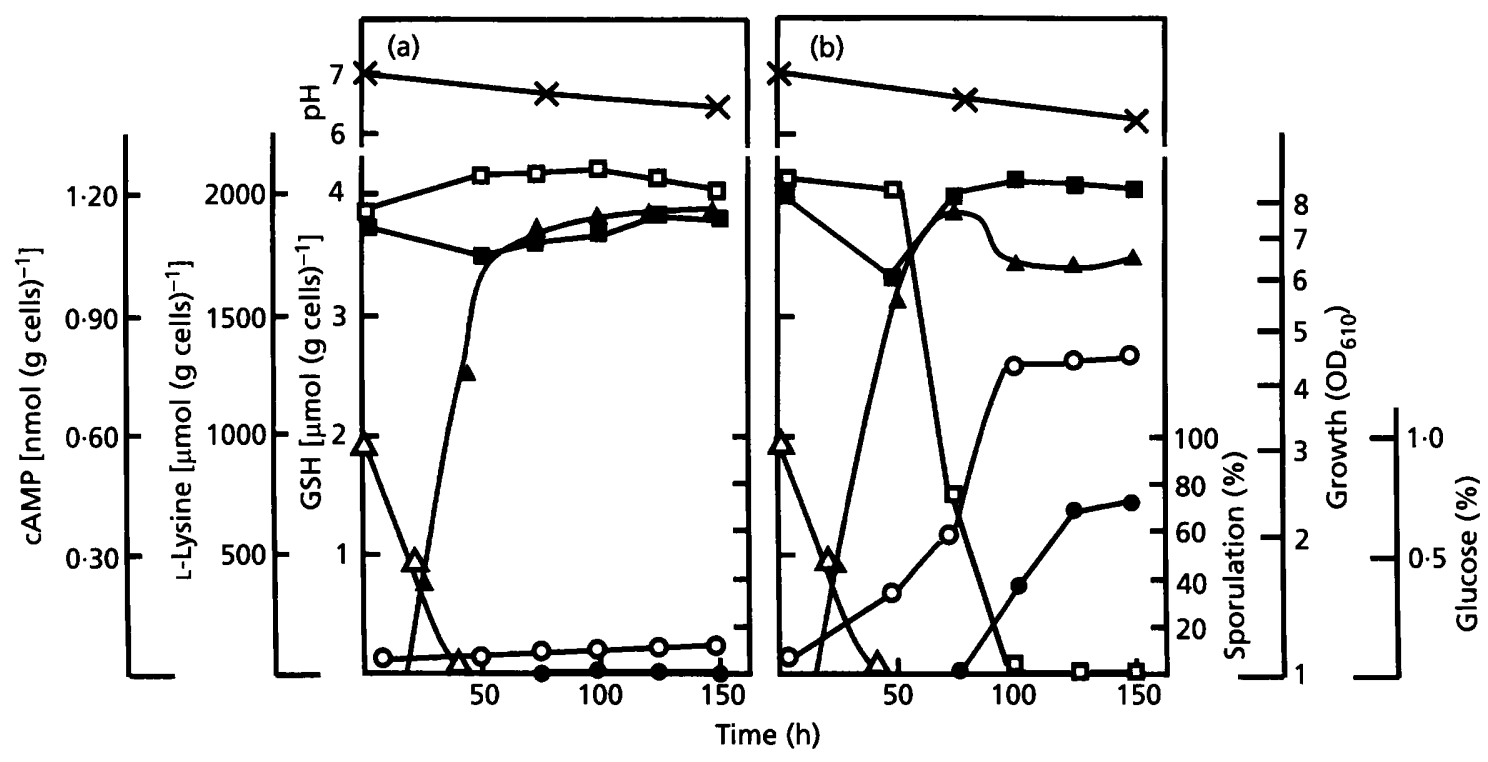

Fig. 4. Changes in cellular glutathione, L-lysine and CAMP levels during sporulation. Cells were incubated in NR medium with (b) and without (a) $0.1 \mathrm{M}$ L-lysine. At the prescribed time, growth $\left(\mathrm{OD}_{610}\right)(\Delta)$, glucose $(\triangle), \mathrm{pH}(+)$, sporulation $(\mathbf{O})$ and intracellular concentrations of glutathione $(\square)$, L-lysine $(O)$ and CAMP $(\square)$ were determined.

Minus L-lysine
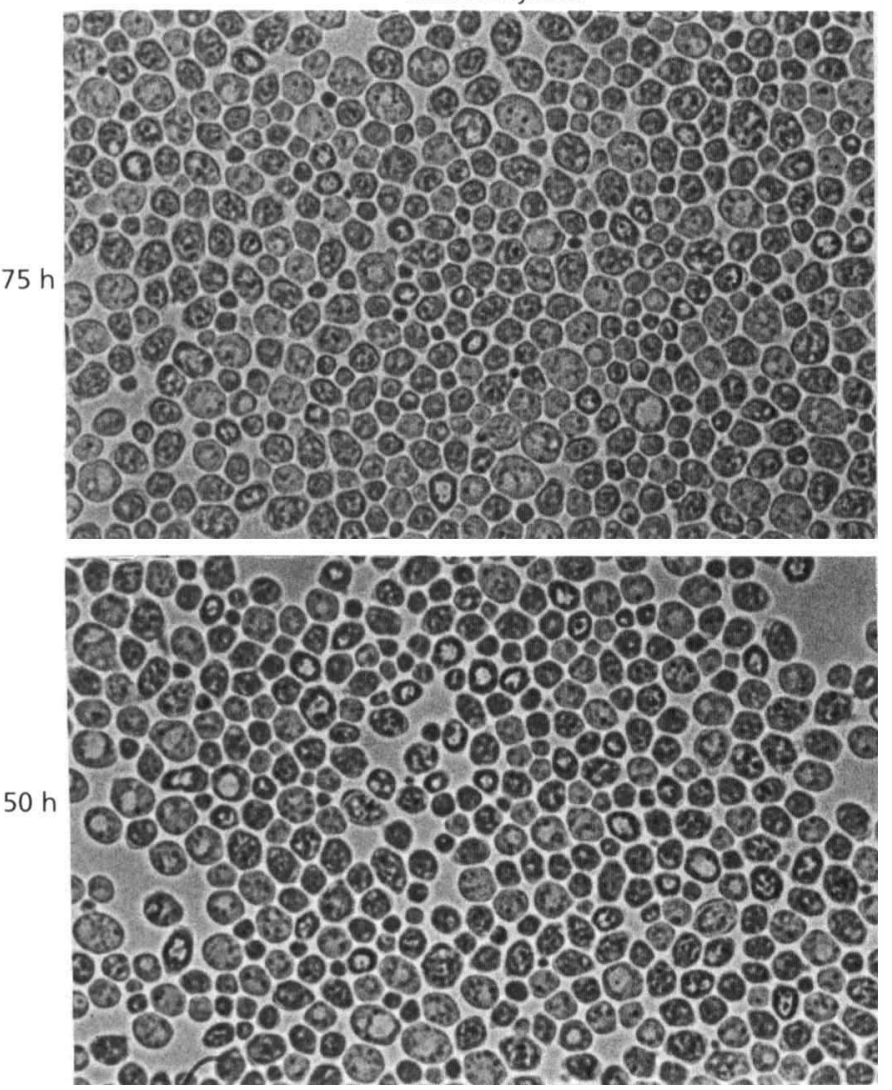

Plus L-lysine
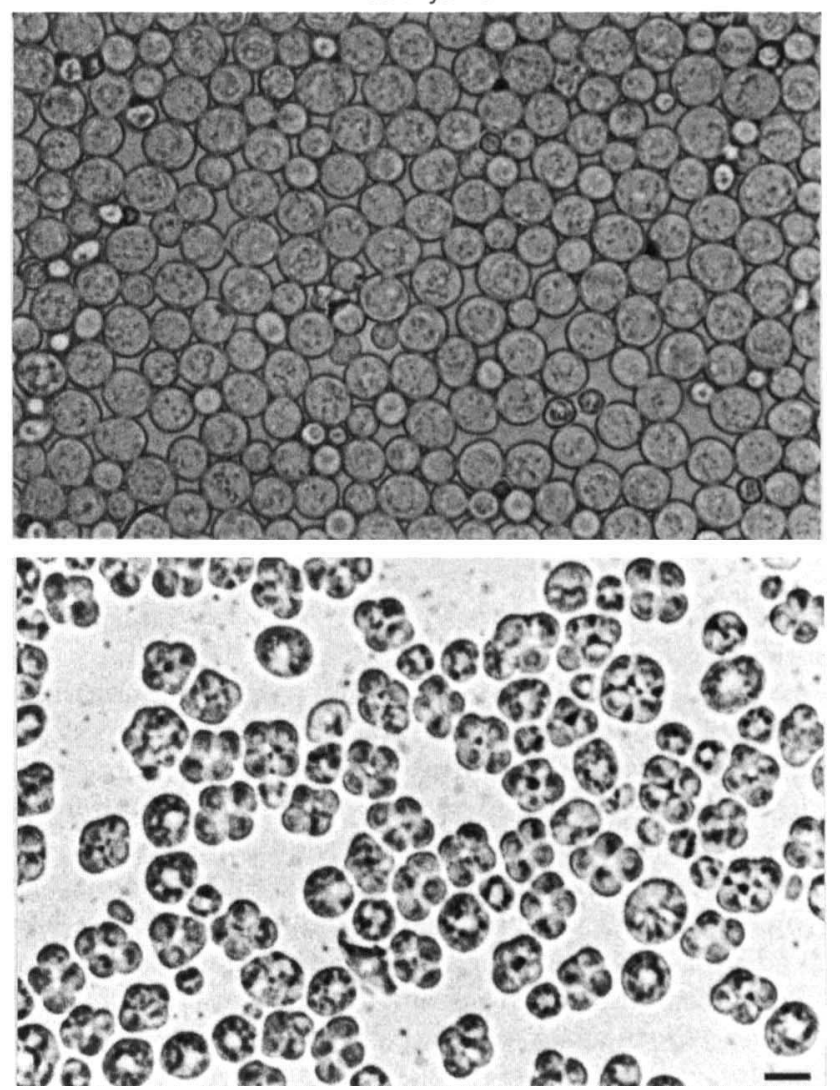

Fig. 5. Changes in cell shape during sporulation. Cells were incubated in the absence (left) and presence (right) of $0.1 \mathrm{M}$ L-lysine in NR medium as indicated in Fig. 4. After incubation for $75 \mathrm{~h}$ (top) and $150 \mathrm{~h}$ (bottom), the cell shapes were microscopically examined. Bar, $10 \mu \mathrm{m}$. 
Table 2. Change in cellular amino acid concentration during sporulation

Cells were grown in NR medium with and without L-lysine $(0.1 \mathrm{M})$ for 50 and $75 \mathrm{~h}$, which correspond to the culture times shown in Fig. 4. Amino acid composition was determined as described in Methods. ND, Not detected.

\begin{tabular}{|c|c|c|c|}
\hline \multirow[t]{3}{*}{$\begin{array}{l}\text { Amino } \\
\text { acid }\end{array}$} & \multicolumn{3}{|c|}{$\begin{array}{l}\text { Amino acid concn } \\
{\left[\mu \mathrm{mol}\left(\mathrm{g} \mathrm{cells}^{-1}\right]\right.}\end{array}$} \\
\hline & \multirow{2}{*}{$\begin{array}{c}\begin{array}{c}\text { Minus } \\
\text { L-Lysine }\end{array} \\
75 \mathrm{~h}\end{array}$} & \multicolumn{2}{|c|}{$\begin{array}{c}\text { Plus } \\
\text { L-Lysine }\end{array}$} \\
\hline & & $50 \mathrm{~h}$ & $75 \mathrm{~h}$ \\
\hline Asp & ND & $7 \cdot 33$ & $11 \cdot 0$ \\
\hline Thr & 307 & 151 & $86 \cdot 0$ \\
\hline Ser & $30 \cdot 7$ & $43 \cdot 0$ & 107 \\
\hline Glu & 483 & 210 & 136 \\
\hline Gly & $41 \cdot 7$ & $16 \cdot 7$ & $12 \cdot 3$ \\
\hline $\mathrm{Ala}$ & 180 & $72 \cdot 3$ & $37 \cdot 7$ \\
\hline Cys & $56 \cdot 0$ & 142 & 416 \\
\hline Val & $46 \cdot 7$ & $31 \cdot 0$ & $31 \cdot 0$ \\
\hline Met & ND & $2 \cdot 67$ & $7 \cdot 33$ \\
\hline Ile & $16 \cdot 3$ & $12 \cdot 3$ & $8 \cdot 33$ \\
\hline Leu & $9 \cdot 33$ & $12 \cdot 0$ & $9 \cdot 00$ \\
\hline Tyr & $7 \cdot 33$ & $11 \cdot 7$ & $9 \cdot 67$ \\
\hline Phe & $10 \cdot 7$ & 6.33 & $14 \cdot 0$ \\
\hline Lys & $77 \cdot 3$ & 430 & 1370 \\
\hline His & $30 \cdot 7$ & $7 \cdot 00$ & $9 \cdot 33$ \\
\hline Arg & 173 & $44 \cdot 7$ & $27 \cdot 0$ \\
\hline Pro & 503 & $6 \cdot 33$ & 113 \\
\hline
\end{tabular}

without L-lysine, glutathione concentration was slightly increased (Fig. 4a).

CAMP. Irrespective of the presence (Fig. 4b) or absence (Fig. 4a) of L-lysine in NR medium, no appreciable changes of intracellular cAMP level were observed, except for a transient decrease (not more than $15 \%$ ) in cells grown with L-lysine.

Proteins. Proteins in cells grown in the absence and presence of L-lysine were analysed (Fig. 6). Cells in the early stationary phase in both cultures (incubation time $75 \mathrm{~h}$ in Figs 4a and b) gave very similar protein profiles, except for an additional $15 \mathrm{kDa}$ protein in L-lysine-grown cells.

\section{DISCUSSION}

Nutrient-deficient medium containing potassium acetate has been utilized for analysis of meiosis and/or sporulation processes of $S$. cerevisiae. This nutrient-deficient medium may be suitable for the analysis of differentiation processes, since it is simple in composition. However, for induction of meiosis and/or sporulation in nutrientdeficient medium, yeast cells have to be transferred from nutrient-rich medium to nutrient-deficient medium. This

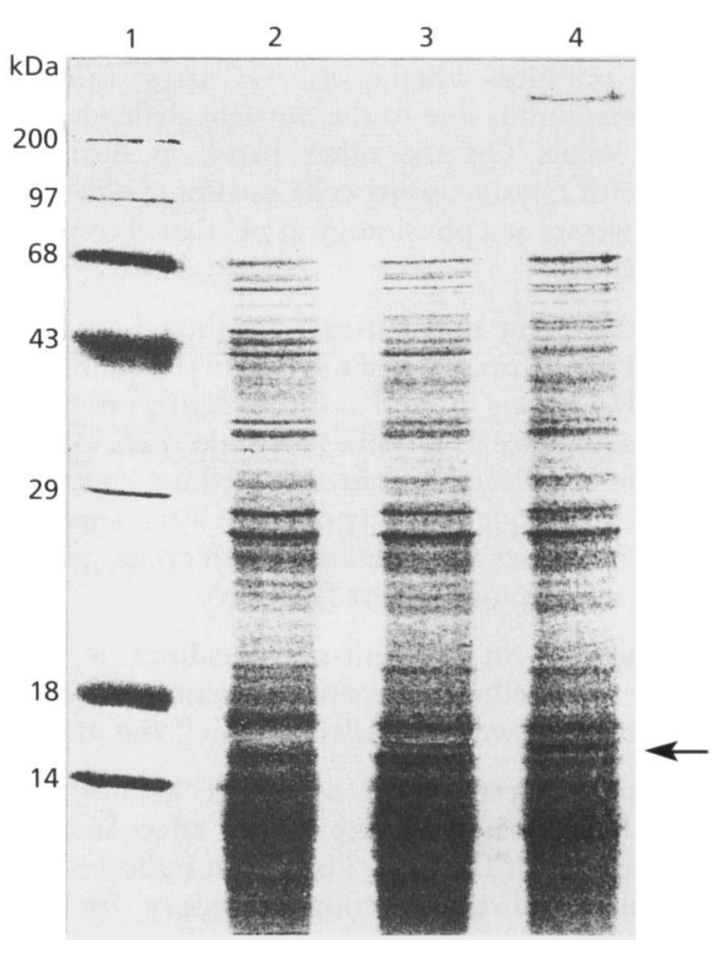

Fig. 6. The $15 \mathrm{kDa}$ protein formed in the presence of L-lysine. Cells were grown in NR medium with (Fig. 4b) or without (Fig. 4a) $0.1 \mathrm{M}$ L-lysine, and proteins in the cells were analysed by SDS-PAGE. Lane 1, standard proteins (from top): myosin ( $\mathrm{H}-$ chain), $200 \mathrm{kDa}$; phosphorylase $b, 97 \mathrm{kDa}$; bovine serum albumin, $68 \mathrm{kDa}$; ovalbumin, $43 \mathrm{kDa}$; $\alpha$-chymotrypsinogen, $25 \mathrm{kDa}$; $\beta$-lactoglobulin, $18 \mathrm{kDa}$; lysozyme, $14 \mathrm{kDa}$. Lane 2 , cells grown for $50 \mathrm{~h}$ in the absence of L-lysine; lanes 3 and 4, cells grown for 50 and $75 \mathrm{~h}$, respectively, in the presence of L-lysine (the $15 \mathrm{kDa}$ protein is indicated by an arrow).

abrupt change in nutritional conditions inevitably gives rise to some irrelevant responses other than those specific to meiosis and/or sporulation. Furthermore, sporulation in nutrient-deficient medium is dependent on the concentration of cells transferred from nutrient-rich medium, and yeast cells cannot sporulate when the cell concentration is less than $10^{5} \mathrm{ml}^{-1}$ (Yamashita et al., 1994). In contrast to the nutrient-deficient conditions used previously, the nutrient-rich medium supplemented with $\mathrm{L}$-lysine enables yeast cells to enter into meiosis and subsequent sporulation processes in the same medium, and meiosis and/or sporulation events can be analysed continuously.

The analysis of the L-lysine-dependent yeast sporulation system in nutrient-rich conditions revealed some characteristic features of the system and processes of meiosis and/or sporulation.

\section{Properties of the L-lysine-dependent sporulation system}

(i) In the course of sporulation in nutrient-deficient medium containing potassium acetate, the $\mathrm{pH}$ of the medium increases, roughly from 7 to 9 (Table 1). Since the 
yeast cells cannot grow at a $\mathrm{pH}$ above 8 (Fig. 1), it is an intriguing question whether the G1 arrest in nutrientdeprived medium is due to the nutrient-deficiency or the high $\mathrm{pH}$ value. On the other hand, in nutrient-rich medium with L-lysine, yeast cells can enter into differentiation processes at a physiological $\mathrm{pH}$ that allows growth (Figs 1 and 3).

(ii) Sporulation in nutrient-rich medium is completely dependent on the presence of L-lysine in the medium (Figs 2, 3 and 4). Among D- and L-amino acids, only D-lysine can be used in place of L-lysine (Kawado et al., 1993). The sporulation of cells in nutrient-rich medium containing Llysine is not a unique property of strain 4011, since similar sporulation kinetics were obtained with other, genetically unrelated, a $/ \alpha$ diploid strains (Fig. $3 b$ ).

(iii) Sporulation in nutrient-rich medium is initiated when the intracellular L-lysine content reaches about $0 \cdot 2-0 \cdot 5 \mathrm{mmol}$ [g (wet wt) cells] ${ }^{-1}$ (Figs 2 and $4 \mathrm{~b}$ ).

(iv) Potassium acetate has no effect in nutrient-rich medium (Fig. 3), and L-lysine has no effect in nutrientdeficient medium (Table 1). This result indicates that the nutritional signal transduction necessary for meiosis and/or sporulation in nutrient-rich conditions is different from that in nutrient-deficient conditions.

\section{Properties of meiosis and/or sporulation processes}

(i) The yeast cells become large and round just before sporulation (Fig. 5). The irregular turbidity changes observed in the presence of L-lysine at various concentrations (Figs 3 and $4 \mathrm{~b}$ ) may either reflect the change in cell size during formation of asci, or be an optical effect caused by a change in the proportion of cells with buds in the population.

(ii) Before entrance into meiosis and/or sporulation in nutrient-rich medium with L-lysine, large amounts of Lcysteine were accumulated in addition to L-lysine (Table 2 ), although glutathione disappeared in association with the onset of sporulation (Fig. 4b). Glutathione has recently been proved to be indispensable for yeast sporulation (Suizu et al., 1994a). The functions of Lcysteine and glutathione are not yet clear.

(iii) No marked changes in intracellular cAMP levels were observed before and after entrance into sporulation processes (Fig. 4b). Matsumoto et al. (1982, 1983, 1984, 1985) proposed that initiation of meiosis may require a low level of cAMP or absence of cAMP-dependent protein kinase. Our results obtained in the L-lysinedependent system go against their hypothesis, and support the results of Olempska-Beer \& Freese (1987) and Cameron et al. (1988). Olempska-Beer \& Freese (1987) showed, in nutrient-rich conditions, that the intracellular cAMP level is irrelevant to meiosis and/or sporulation and that guanine nucleotides have a crucial role as differentiation signals. Cameron et al. (1988) also indicated that cAMP-independent mechanisms must exist for regulating sporulation processes, since sporulation of mutants with disruptions in TPK1-TPK3, genes for catalytic subunits of cAMP-dependent protein kinase, is still regulated by nutrients. The observed change in cAMP level observed by Matsumoto and co-workers may be due to the stress adaptation of cells suddenly transferred to nutrient-deficient medium from nutrient-rich medium.

(iv) Although a more definitive conclusion on the function of the Ras/cAMP pathway in yeast differentiation processes is required, we attach importance to the function of $\mathrm{Ca}^{2+}$ in meiosis and/or sporulation. $\mathrm{Ca}^{2+}$ is indispensable for sporulation (Suizu et al., 1994b) and is supplied through the influx of external $\mathrm{Ca}^{2+}$ rather than by release from internal calcium stores (unpublished). In this context, the $15 \mathrm{kDa}$ protein that is specifically produced by the yeast cells grown in nutrient-rich medium with Llysine (Fig. 6) may be significant, since a protein with the same molecular size has been identified as an endogenous substrate for a $\mathrm{Ca}^{2+} /$ calmodulin-dependent protein kinase in Fusarium oxysporum (Hoshino et al., 1992).

\section{REFERENCES}

Cameron, S., Levin, L., Zoller, M. \& Wigler, M. (1988). cAMPindependent control of sporulation, glycogen metabolism, and heat shock resistance in S. cerevisiae. Cell 53, 555-566.

Freese, E. B., Chu, M. I. \& Freese, E. (1982). Initiation of yeast sporulation by partial carbon, nitrogen, or phosphate deprivation. J Bacteriol 149, 840-851.

Freese, E. B., Olempska-Beer, Z., Hartig, A. \& Freese, E. (1984). Initiation of meiosis and sporulation of Saccbaromyces cerevisiae by sulfur or guanine deprivation. Dev Biol 102, 438-451.

Hoshino, T., Mizutani, A., Hidaka, H. \& Yamane, T. (1992). Identification of $\mathrm{Ca}^{2+} /$ calmodulin-dependent protein kinase and endogenous substrate of Fusarium oxysporum. FEMS Microbiol Lett 94, 27-30.

Kano, K., Murata, K., Kimura, A. \& Aiba, H. (1983). Cloning and amplification of the adenylate cyclase gene. Agric Biol Chem 47, 1079-1085.

Kawado, A., Suizu, T., Imayasu, S., Kimura, A. \& Murata, K. (1993). Yeast sporulation induced by lysine during growth in nutrition-rich conditions. J Ferment Bioeng 76, 391-394.

Laemmli, U. K. (1970). Cleavage of structural proteins during the assembly of the head of bacteriophage T4. Nature 227, 680-685.

Matsumoto, K., Uno, I., Oshima, Y. \& Ishikawa, T. (1982). Isolation and characterization of yeast mutants deficient in adenylate cyclase and cAMP-dependent protein kinase. Proc Natl Acad Sci USA 79, 2355-2359.

Matsumoto, K., Uno, I. \& Ishikawa, T. (1983). Initiation of meiosis in yeast mutants defective in adenylate cyclase and cyclic AMPdependent protein kinase. Cell 32, 417-423.

Matsumoto, K., Uno, I. \& Ishikawa, T. (1984). Identification of the structural gene and nonsense alleles for adenylate cyclase in Saccharomyces cerevisiae. J Bacteriol 157, 277-282.

Matsumoto, K., Uno, I. \& Ishikawa, T. (1985). Genetic analysis of the role of cAMP in yeast. Yeast $1,15-24$.

Olempska-Beer, Z. \& Freese, E. (1987). Initiation of meiosis and sporulation in Saccharomyces cerevisiae does not require a decrease in cyclic AMP. Mol Cell Biol 7, 2141-2147.

Suizu, T., Tsutsumi, H., Ohtake, Y., Kawado, A., Imayasu, S., Kimura, A. \& Murata, K. (1994a). Absolute glutathione requirement for sporulation of a yeast Saccharomyces cerevisiae. Biochem Biopbys Res Commun 205, 1151-1155. 
Suizu, T., Tsutsumi, H., Kawado, A., Murata, K. \& Imayasu, S. (1994b). On the importance of calcium and magnesium ions in yeast sporulation. J Ferment Bioeng 77, 275-277.

Tietze, F. (1969). Enzymatic method for quantitative determination of nanogram amounts of total and oxidized glutathione. Anal Biocbem 27, 502-522.
Yamashita, I. (1994). Pheromone that induces meiosis in Saccharomyces cerevisiae. Nippon Nogeikagaku Kaishi (Journal of the Agricultural Chemical Society of Japan) 68, 100 (in Japanese).

Received 8 March 1995; revised 31 May 1995; accepted 6 June 1995. 